\title{
An Empirical Study on EQ Cultivation Education of Underachievers Based on Maslow's Hierarchy of Needs
}

\author{
Bangxiong Xie \\ Luxian No. 2 High School, Luzhou, China \\ Email: 47872614@qq.com
}

How to cite this paper: Xie, B. X. (2021). An Empirical Study on EQ Cultivation Education of Underachievers Based on Maslow's Hierarchy of Needs. Open Journal of Social Sciences, 9, 375-381. https://doi.org/10.4236/jss.2021.95019

Received: April 29, 2021

Accepted: May 16, 2021

Published: May 19, 2021

Copyright (อ 2021 by author(s) and Scientific Research Publishing Inc. This work is licensed under the Creative Commons Attribution International License (CC BY 4.0).

http://creativecommons.org/licenses/by/4.0/

\section{(c) (i) Open Access}

\begin{abstract}
Children's lack of EQ education has become the bottleneck of high school education, that is, the excellent students are no longer excellent or even become underachievers after entering high school. Therefore, the transformation education of these "underachievers" has become the important tasks of the head teacher. Goal education and inspirational education are the core tasks throughout. Many students "are easier to aspire to than to persist". In the transformation education of these underachieving students, the cultivation of EQ is particularly important. Based on Maslow's hierarchy of needs, this paper classifies the underachievers according to the difference of psychological needs and makes an in-depth analysis of the characteristics of psychological needs of the underachievers in different levels of needs to seek for the reasons that influence and cause the deviation of emotional intelligence of the underachiever, and then carries out an empirical study on the incentive transformation strategy of the underachievers, which aims to explore the effective incentive mechanism of EQ training education for underachieving students.
\end{abstract}

\section{Keywords}

Underachiever, Psychological Need, EQ Cultivation, Empirical Study

\section{The Proposal and Theoretical Basis of the Problem}

Emotional Intelligence (EQ), also known as emotional intelligence, is a concept put forward by psychologists in recent years, which is corresponding to intelligence and IQ, which mainly refers to people's quality in the mood, emotion, will, tolerance to setbacks and other aspects ( $\mathrm{Lu}, 2005)$. In the past, many people were 
biased to believe that intelligence is the first important factor in one's success in life. That is the higher your IQ, the more likely you are to achieve. But it is now widely accepted by psychologists that emotional intelligence, sometimes more than intelligence, plays a significant role in determining success. In fact, students in the stage of high school, who can always maintain the state of diligent, excellent and stable must have the excellent qualities like strong will, clear goals, and the key is to be able to bear hardships. This is the so-called "emotionally intelligent" students.

Jinzhan Wang, a contemporary educator, once said, "Another standard in today's society to evaluate a person's success is whether he or she can raise a successful child" (Wen, 2007). This shows that for children's education, especially high school children's education is very important and the task is difficult. Under the influence of the current exam-oriented education and social competition pressure, parents and schools tend to pay too much attention to academic performance while ignoring the cultivation of children's $\mathrm{EQ}$, that is, the phenomenon of "high scores but low abilities" is more common. As the saying goes, "no Germany is no waste, there is no Germany is a semi-finished product, there is no Germany is dangerous goods, there is Germany is a boutique". It can be seen that the cultivation of EQ and knowledge and culture education are equally important for a student.

However, under the current educational environment, the lack of EQ education for many children has become the bottleneck of high school education, that is, "excellent students in middle will no longer be excellent or even become underachievers after entering high school". The transformation education of these "poor students" that is, the so-called "underachiever" has naturally become one of the important tasks of the teacher in charge. Over the years, I have summarized some experience in the exploration and practice of EQ education for underachieving students, that is: according to students' psychological needs, give them appropriate incentives and education. This idea comes from the psychologist Maslow's hierarchy of needs.

Maslow, a famous American psychologist, pointed out: the intrinsic power of individual growth and development is motivation. Motivation is composed of various needs of different nature, among which there is a sequence of a high and low level. The need and satisfaction of each level will determine the state or degree of individual personality development (Liu, 2021). According to the hierarchy of needs theory, for researching convenience, in this paper, students are classified and compared according to their needs. Different levels of students have different levels of needs: students who cannot take care of their personal material life or who have difficulties in material life are in the level of physiological need; students with disharmonious family relationship, divorced parents and lack of care are in the level of safety and social needs; students with established ideal goals, but poor learning foundation are in the level of respect and self-realization. According to the different needs of these students to design their 
educational content and incentive mechanism, it can play an effective incentive role.

\section{The Characteristics of Different Levels of Students}

We can divide the underachievers of a class into three categories, namely the basic underachiever, the middle underachiever and the senior underachiever.

1) The first class of underachiever is the main part of the class of students with academic difficulties, including students whose academic performance is unstable or backward due to material life difficulties and students with poor self-management ability. This kind of students is in the grass-roots level because the number of its proportion is significant. Some of these students may sometimes struggle financially to stay in school because of family difficulties, the situation of which makes these students puts a lot of pressure, cannot devote themselves to study, and even produce serious inferiority complex and escape weariness of study mood, causing its achievement to decline rapidly to become students with learning difficulties finally. Another part of the students are often poor because of poor life management ability, unable to plan and organize their daily life and although the living expenses provided by their parents were never in short supply, they could not control his consumption and spent lavishly. They are often extravagant at the beginning of the month, in the middle of the economy barely maintain, and in the second half of the month live in debt because "run out of grain". In addition, such students are disliked by the group because they are lazy. These students often suffer from the problem of "food and clothing", no intention to learn and cause academic results lag behind and waste.

2) The second type of underachiever is the one who is more active in the class and most likely to have a negative impact on other students. These students usually have good family economic conditions, but due to factors like family discord, divorce, family combination or parents busy with work for a long time and seldom living with their children, which lead to such students' lack of communication with their parents, lack of sense of belonging to their families, and even hostility to their parents. Such students also have stubborn character, bad-tempered, love to lie and other characteristics, usually accompanied by computer geek, truancy, smoking, drinking, fighting, puppy love and other behaviors. Such students are difficult to persuade because of their emotional distrust of others. However, because of their subliminal need for family care and attention and recognition from others, they are emotionally fragile and sensitive.

3) The third kind of students have higher ideal goals, but because of poor learning foundation, unreasonable learning methods and other reasons, resulting in unsatisfactory academic performance. For a long time in the gap of the difference between ideal and reality, the self-confidence is seriously damaged, and even produce inferiority complex. Such students are usually more serious in learning and relatively practical in doing things, but they cannot improve their methods reasonably. They are in urgent need of recognition from teachers and 
classmates in learning and need to prove their learning ability by improving their academic performance, thus at the level of respect and self-actualization.

\section{Incentive Methods and Case Analysis of Students with Different Needs Levels}

\subsection{Incentive Methods for Students of Different Levels}

1) The pertinence of incentive measures should be strengthened, and the incentive intensity should be reasonably regulated to enhance the incentive effect. The head teacher should aim at the problem that the incentive is not strong, the strength is not enough, the effect is not obvious, carry on the corresponding targeted incentive according to the difference of the students. Students' needs vary from person to person and from time to time. As a class teacher, we should improve the incentive mechanism in time according to the difference of students' needs and class development stage, so as to exert the effect of the incentive mechanism to the maximum extent. At the same time, the incentive mechanism should implement multi-level differential incentive.

2) We should pay equal attention to material and spiritual incentives, and should not favour one over the other. The head teacher should adhere to the principle of combining material incentive with spiritual incentive when establishing and improving the incentive mechanism both of which are indispensable and cannot replace each other at the same time.

3) The combination of short-term incentive and long-term incentive as well as the establishment of management ledger, let the students develop the habit of gratitude account.

4) Establish a scientific and reasonable incentive mechanism to improve the pertinence and effectiveness of incentives (Table 1).

\subsection{Case Study}

\section{Case 1: A Gui-the positive energy of the class}

A Gui was one of my students graduated in 2013, who was admitted to Sichuan Normal University when graduated from high school. Now he has graduated and started to work. In my class at that time, A Gui was the model of the students, the model of hard work, the model of learning, and the model of helping others. He is the positive energy of the class.

However, when he first entered the class, he was a veritable underachiever in my class. Because this student's enrollment basis is too poor, the learning state is very unstable, usually do not talk and is of bad presence. When the results of the first half of the senior high school examination were announced, he was the fifth from the bottom of the class. So I began to get to know this student consciously and actively. According to the information I have learned to show: the student's family is very poor and his father are not concerned about the family and became lost after worked outside in the early years. His mother works on the farm at home, and his sister is studying in junior high school. His economic expenses 
Table 1. Design of incentive methods for students at different levels.

\begin{tabular}{|c|c|c|c|}
\hline student type & $\begin{array}{l}\text { hierarchy } \\
\text { of needs }\end{array}$ & $\begin{array}{l}\text { Incentive method design and } \\
\text { objective of EQ training }\end{array}$ & case \\
\hline basic level & $\begin{array}{l}\text { physiological } \\
\text { needs }\end{array}$ & $\begin{array}{l}\text { Method: 1) care about their material life, try to help } \\
\text { them to solve the difficulties in life. 2) Supervise } \\
\text { their reasonable arrangement of life, cultivate their } \\
\text { ability to manage life, especially to develop the habit } \\
\text { and ability of financial management. 3) Growth } \\
\text { experience and inspirational ideal education. } \\
\text { Goal: To develop the ability to properly manage } \\
\text { emotions and achieve goals as well as self-discipline. }\end{array}$ & $\begin{array}{l}\text { case } 1 \\
\text { case } 2\end{array}$ \\
\hline middle-level & $\begin{array}{c}\text { Safety } \\
\text { and social } \\
\text { belonging needs }\end{array}$ & $\begin{array}{l}\text { Methods: 1) To strengthen the contact between } \\
\text { home and school, and to coordinate the work of } \\
\text { parents. 2) Guide children to re-enter the family, } \\
\text { create opportunities for them to experience family } \\
\text { love and friendship, experience the truth, kindness } \\
\text { and beauty in social life. 3) Motivational education } \\
\text { and ideal education. } \\
\text { Objective: To develop the ability to properly } \\
\text { manage emotions, understand the emotions of } \\
\text { others, achieve goals and restrain self behavior. }\end{array}$ & case 3 \\
\hline high level & $\begin{array}{c}\text { Respect and } \\
\text { self-actualization } \\
\text { needs }\end{array}$ & $\begin{array}{l}\text { Methods: 1) Confidence cultivation. 2) Study me- } \\
\text { thod guidance and successful experience to enhance } \\
\text { confidence. 3) Inspirational education. } 4 \text { ) The } \\
\text { correct outlook on life, values, guidance and training } \\
\text { of career development concept. } \\
\text { Objective: To develop the ability of self-awareness, } \\
\text { self-motivation, goal realization and interpersonal } \\
\text { relationship management. }\end{array}$ & $\begin{array}{l}\text { case } \\
\text { (omit) }\end{array}$ \\
\hline
\end{tabular}

are basically supported by his uncle and other relatives and A Gui once dropped out of school for two years for lack of money to go to school. The decision to re-enter high school came after he dropped out of school for two years to work in Beijing. However, because the reality was too cruel, he did not have a good foundation in study. At the same time, he often wanted to give up several times due to financial constraints. When I learned about this information, I was very moved and sympathized with his experience, so I immediately took effective incentive measures: first of all, inspirational mobilization in thought. The second is to start the love-work-study fund of class-with the unanimous consent of all the parents and students, each student will contribute 5 yuan per month to clean the classroom and the public area for A Gui. At that time, there were 81 students in my class and they could raise 400 yuan a month for their special fund. From then on, A Gui went to the classroom early in the morning at 6:00 every morning to clean up, and then hurriedly went to clean up the public area. Afternoon after school, when the other students all went to dinner, he cleaned up as usual and just eat steamed bread or instant noodles after sweeping, with no time to eat. Every day he cleaned as usual, and he was highly regarded by the whole class. From then on, A Gui studied very hard. Every day, A Gui studies every minute. At night, A Gui spends time reading under the street lamp in the dormitory corridor until late into the night. At the end of the term, he ranked first in his class. 
In addition, A Gui is very enthusiastic to help every classmate who asks for help from him.

As a result, A Gui became the image representative of the positive energy of the class. He influenced and led the students in the class to embark on the road of hard work and hard work.

Case 2: A Yong-it was all caused by lack of money to eat

A Yong, a former student of 2010, is another typical underachiever at the grassroots level. At the beginning of the school, the student is very sunny and popular among students, the rich guy of the class. However, after a period of time, I found that he was very abnormal in his studies. He is absent-minded in class and has a bad study state and often ask for sick leave to rest in the dormitory and do not come to the evening study. Once again, he was absent as usual, and I quietly asked his roommate in the dorm and find out a surprising discovery. A student told me: "Teacher, Yong has not eaten for two days!" After further understanding, the truth gradually emerged: the child was very poor at managing life and could not plan and arrange his daily life. Although the living expenses provided by his parents were never short, he was often in poverty because he could not control his consumption and spent lavishly. They are often extravagant at the beginning of the month, in the middle of the economy barely maintain, and in the second half of the month live in debt because "run out of grain". Every day living in the worry of the "livelihood", he doesn't want to study of course. Therefore, I decisively communicated with Yong's parents and asked him to live in my home (I had a house on campus at that time) so that I could control his daily life. The first step of the implementation of control is that the parents save the living expenses in my account and the child receives the living expenses by week. I urge and guide the children to keep a good record of expenses every day, and make a good budget and settlement of funds every week. If the funds are well managed, they will be rewarded in time. The second step is to help me do housework properly at my home every weekend, and I will give certain rewards and rewards. Gradually, he developed the habit of sorting out the details of his personal life. With the timely encouragement from his teachers and parents, he began to enter the learning state gradually. When he graduated, Yong was admitted to his favorite university.

Case 3: Xiao Jiang-it's not that she doesn't care, but she's too tangled

Xiao Jiang, a student in my class of 2014 in Luxian No. 2 High School, is the "nail households" among the underachieving students. He was a student who had been suspended from school in the previous grade. He quit school because he used to be too tired of learning and has psychological disorders (once "study abroad" for half a year to a professional psychological correction school). The child is unlearning, cranky, lazy and unhygienic. The other children often stayed away from him. As a result, he and the class did not get along, and several times came close to a violent conflict. I began to explore his background and the reasons for his deviations. The specific situation is: her parents divorced at an early age and her mother is a police officer, whose professional characteristics make 
her simple and rough education of her children, and thus the children cannot communicate with her...

I started a specific plan for Xiaojiang's incentive transformation measures: First of all, I invited her mother to the school for several times to have three-party "discussions" with Xiao Jiang's roommates and me. We discussed how to give him one-to-one assistance starting from his roommate in the dormitory. Each student is responsible for a specific project: some are responsible for leading and supervising Xiao Jiang to clean up the house, some take turns to ask Xiao Jiang to go shopping in the supermarket, go to the canteen to eat, some supervise him to finish the homework, and sometimes ask him to play basketball with him, etc. In short, let him find the feeling of "home" first, let him feel that there are classmates who care about him and there are teachers who pay attention to him. Secondly, two parents are required to accompany their children to school regularly, participate in parent-child activities, and let their children experience affection again. Finally, it is appropriate to carry on the growth education and the ideal inspirational education, and give praise to its progress in time. Little by little, Xiao Jiang became sunny and could not only get together with the students in his class, but also was humorous and popular. As for his inner world, Xiaojiang himself said, "Once, I wasn't not care about my family and study life, but I was too entangled...”.

Later, Xiaojiang's condition was normal and he made great progress in all aspects. He joined the army when he was about to graduate and is still serving in the army now.

\section{Conclusion}

Education is a knowledge and the teacher in charge of the work needs to comply with science and advance with The Times. For the cultivation and transformation of the underachiever, we can only "make a concrete analysis of the specific problems of the specific students", starting from the cultivation of the students' $\mathrm{EQ}$ and encouraging them according to the level differences of their psychological needs, so as to get twice the result with half the effort.

\section{Conflicts of Interest}

The author declares no conflicts of interest regarding the publication of this paper.

\section{References}

Liu, T. (2021) See the Rabbit Is Rich from Maslow's Hierarchy of Needs Theory. Journal of Ancient and Modern Times, 9, 12-14.

Lu. J. M. (2005) An Exploration of the Concept of Emotional Intelligence. Journal of Psychological Science, 5, 1246-1249.

Wen, J. (2007) There Are No "poor students", Only the Students Who Are Temporarily Behind-An Interview with Jinzhan Wang, a National Excellent Teacher. Perspectives on Education, 4, 1-13. 